\title{
Utility of HAPS for predicting prognosis in acute pancreatitis
}

\author{
(1) Ali Vefa Sayraç, M.D., ${ }^{1}$ ' Yıldıray Cete, M.D., ${ }^{2} \odot$ Özlem Yiğit, M.D., ${ }^{2}$

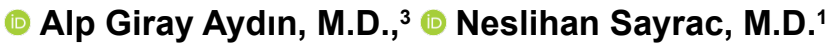 \\ ${ }^{1}$ Department of Emergency Medicine, Antalya Training and Research Hospital, Antalya-Turkey \\ 2Department of Emergency Medicine, Akdeniz University Faculty of Medicine, Antalya-Turkey \\ ${ }^{3}$ Department of Emergency Medicine, Koç University Faculty of Medicine Hospital, İstanbul-Turkey
}

\begin{abstract}
BACKGROUND: Acute pancreatitis (AP) is a common abdominal disorder, which requires early diagnosis and treatment. Several prognostic scoring systems introduced to clinical practice are not suitable in emergency department (ED) because these require much time and complex parameters. Recently, the harmless acute pancreatitis score (HAPS) has been introduced to identify AP with a nonsevere course. The aim of this study was to determine the utility of HAPS in predicting the severity of AP.
\end{abstract}

METHODS: All patients aged >16 years who were diagnosed as AP in ED were enrolled in this retrospective study. The study included I 44 patients with a mean age of $58.7 \pm 15.4$ years, and 69 (47.9\%) of them were males and 75 (52.1\%) were females. Patient data were collected from hospital database. The utility of HAPS was analyzed and compared using the Ranson's score.

RESULTS: HAPS was statistically significant for predicting mild disease $(p=0.008)$ and has demonstrated a specificity of $81 \%$, a positive predictive value (PPV) of $96 \%$, and an odds ratio of 5.57 (I.5I-20.50). The predictability of Ranson's scores was not significant. The measure of agreement $(\kappa)$ between the two scores was 0.15 , indicating a low agreement.

CONCLUSION: HAPS is a simple and useful scoring algorithm to predict the non-severe course of AP in ED. HAPS-0 patients did not require early aggressive treatments and advanced radiological screening tools during the early stages of the disease.

Keywords: Acute pancreatitis; emergency medicine; HAPS; prognosis.

\section{INTRODUCTION}

Acute abdominal pain is a common complaint for emergency department (ED) visits and accounts $6.5 \%$ of all ED visits. ${ }^{[1]}$

Acute pancreatitis (AP) usually presents with acute abdominal pain and requires immediate diagnosis and treatment. Approximately $80 \%$ of patients with AP have a mild, uncomplicated course and resolve without severe morbidity, whereas the remaining $20 \%$ develop severe disease and accounts significant morbidity and mortality with local and systemic complications. ${ }^{[2]}$ Deaths occur in approximately $5 \%$ of all patients; however, patients with multi-organ failure carry a mortality risk of up to $47 \%$. Sixty five percent of all deaths occur in the first 14 days and $80 \%$ in 30 days. ${ }^{[3]}$ When AP is diagnosed, it is important to predict the severity of disease early after hospital admission, with objective parameters. If the prediction is truly considered and aggressive management strategies are started immediately, then the mortality and morbidity will decrease.

Because of limited data on patients at ED arrival, an ideal scoring system that involves fewer parameters is easy to recall, and is effective in predicting severe AP early in the evaluation of patients is warranted. ${ }^{[4]}$ Although numerous clinical scoring systems are available to measure and pre-

Cite this article as: Sayraç AV, Cete Y, Yiğit Ö, Aydın AG, Sayrac N. Utility of HAPS for predicting prognosis in acute pancreatitis. Ulus Travma Acil Cerrahi Derg 2018;24:327-332.

Address for correspondence: Özlem Yiğit, M.D.

Akdeniz Üniversitesi Hastanesi, Acil Tıp Anabilim Dalı, Dumlupınar Bulvarı, Kampüs, 07059 Antalya, Turkey.

Tel: +90 242 - 2492285 E-mail: ozlemyigit@akdeniz.edu.tr

Ulus Travma Acil Cerrahi Derg 2018;24(4):327-332 DOI: 10.5505/tjtes.2017.50794 Submitted: 20.06.2017 Accepted: 04.12.2017 Online: 26.06.2018

Copyright 2018 Turkish Association of Trauma and Emergency Surgery 
dict disease severity, most are of limited use to emergency physicians. Several of these scoring systems include complex and multiple calculation parameters, require long periods of hospitalization, and represent inadequate sensitivities. Recently, the harmless acute pancreatitis score (HAPS) has been introduced to identify AP with a non-severe course. ${ }^{[5]}$ The algorithm contains three parameters, including signs of peritonitis or guarding and levels of serum creatinine and hematocrit. The disease course is very likely to be non-severe if all these parameters are normal at the time of admission to the hospital. Compared with the previous scoring algorithms, HAPS is simple and can be assessed within the first hour of the clinical examination of a patient with AP and can help stratify non-severe harmless disease. Therefore, HAPS may be used to identify patients that may not require intensive therapy or imaging studies and may show promise in the simple assessment of AP and consideration for discharge from ED. ${ }^{[6]}$

The aim of this study was to determine the utility of HAPS in predicting the severity of AP in ED.

\section{MATERIALS AND METHODS}

\section{Study Design and Setting}

This study was conducted as a retrospective chart review in an academic ED of a tertiary care university hospital with an annual census of approximately 90,000 adult patient visits. The study was approved by the local ethics committee. After receiving the permission for data collection from the hospital director, ED hospital records for the previous 4 years were searched to identify all patients recorded to the database as acute pancreatitis-code K85 according to the International Classification of Disease-10 (ICD-10) system. Demographic data of patients, physical examination, laboratory and imaging findings, and hospitalization and discharge notes were evaluated, and data were recorded to the study form.

\section{Exclusion Criteria}

Patients aged $<16$ years and those with traumatic pancreatitis were excluded. Patients not diagnosed as pancreatitis but incorrectly coded as acute pancreatitis-code K85 and those with incomplete data from the charts were also excluded. Second admission to ED in 7 days was accepted as the same attack with the previous one, and these second admissions were excluded.

\section{Data Collection}

Signs of peritonitis (either rebound tenderness or guarding), abdominal ultrasound (US) and computed tomography (CT) findings (gallstones and pancreatic necrosis), laboratory findings, the length of hospitalization, need for intensive care unit (ICU), and in-hospital mortality were recorded. The need for ICU care, in-hospital mortality, and hospitalization of $>5$ days were classified as poor prognosis and severe AP.
HAPS was defined as an absence of signs of peritonitis, serum creatinine levels of $<2 \mathrm{mg} / \mathrm{dL}$, and hematocrit levels of $<43 \%$ for males and $<39.6 \%$ for females at the time of admission. Patients were classified as HAPS-0 (zero) if they fulfilled all three criteria and as HAPS+ if any of these were present. Ranson's score data were collected, and first admission scores were calculated. Patients with Ranson's score of $\geq 3$ were suspected to have severe AP.

\section{Statistical Analysis}

Data were analyzed using SPSS 20.0 for Windows statistical package. Continuous data are presented as mean $\pm S D$, and categorical data are presented as frequencies and percentiles. Univariate analyses between two groups for categorical data were performed using chi-square test and Mann-Whitney $U$ test for ordinal data. A two-sided $p$ value of $<0.05$ was considered significant. The measure of agreement Cohen's Kappa ( $\kappa)$ between the two scores (Ranson's score and HAPS) was calculated.

\section{RESULTS}

The study included I 44 patients diagnosed with AP. The mean age was $58.7 \pm 15.4$ years and median age was 61 (range; min. I8, max. 93) years, with a female:male ratio of nearly I:I [75 (52.1\%) females and $69(47.9 \%)$ males]. The most common etiology of AP among the study group was gallstones disease $(n=89,61.8 \%)$. Other etiologies and their distributions of sex are shown in Table I.

HAPS and Ranson's scores were calculated for all patients. There were 75 (52.1\%) patients in the HAPS-0 mild pancreatitis group and the remaining 69 (47.9\%) had at least one parameter positive and were grouped as HAPS+. According to the Ranson's scores, $122(84.7 \%)$ patients were classified as low risk (0-2 points) and 22 (15.3\%) as high risk. The measure of agreement $(\kappa)$ between the two scores was 0.15 , which estimates a slightly low agreement.

All patients in the study group underwent USG examination, and $43(29.8 \%)$ had an abdominal CT imaging. Pancreatic necrosis was present in $12(8.3 \%)$ patients, and $4(30 \%)$ of

Table I. Etiology of acute pancreatitis attacks

\begin{tabular}{lccc}
\hline Diagnosis & Patient (\%) & Male (\%) & Female (\%) \\
\hline Gallstone & $89(6 \mathrm{I} .8)$ & $39(27.1)$ & $50(34.7)$ \\
Alcohol & $2(1.4)$ & $2(1.4)$ & - \\
Pancreas cancer & $7(4.9)$ & $3(2.1)$ & $4(2.8)$ \\
Hyperlipidemia & $2(1.4)$ & $\mathrm{I}(0.7)$ & $\mathrm{I}(0.7)$ \\
Drugs & $3(2.1)$ & $\mathrm{I}(0.7)$ & $2(1.4)$ \\
Other & $4 \mathrm{I}(28.4)$ & $23(15.9)$ & $18(12.5)$ \\
Total & $144(100)$ & $69(47.9)$ & $75(52.1)$ \\
\hline
\end{tabular}


these died during hospitalization (Table 2). HAPS was statistically significant for predicting pancreatic necrosis $(p=0.047)$.

Predefined poor prognosis criteria were found in 68 (47.2\%) patients among the total 144 patients (Table 3). Of these severe AP patients, 38 were males and 30 were females, and the

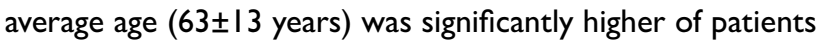
in this group than the whole study patients $(p=0.001)$. Severe AP was more common in pancreatitis etiologies other than gallstones $(p=0.04)$. HAPS was statistically significant for predicting poor prognosis and pancreatitis severity $(p=0.013)$. The statistical significance of HAPS was better than whole, if poor prognosis is considered only as the need for ICU care

Table 2. Predictability of HAPS for pancreatic necrosis

\begin{tabular}{lccc}
\hline & \multicolumn{2}{c}{ Pancreatic necrosis } & p* \\
\cline { 2 - 3 } & Yes (\%) & No (\%) & \\
\hline HAPS-0 & $3(4)$ & $72(96)$ & 0.047 \\
HAPS + & $9(13)$ & $60(87)$ & \\
Total & $12(8.3)$ & $132(9 \mid .7)$ & \\
\hline "Chi-square test. HAPS: Harmless acute pancreatitis score.
\end{tabular}

Table 3. Patients with poor prognosis

\begin{tabular}{lcc}
\hline & n & $\%$ \\
\hline Poor prognosis & 68 & $47.2^{*}$ \\
Death & 8 & 5.6 \\
Intensive care unit (ICU) transfer & 14 & 9.7 \\
$>5$ hospitalizations & 62 & 43.1 \\
\hline
\end{tabular}

"Six patients died in the first 5 days after hospitalization and three died in the general ward before getting transferred to the ICU. 9 patients who were cared in the ICU were discharged from hospital with healing.

Table 4. Predictability of HAPS for poor prognosis

\begin{tabular}{|c|c|c|c|}
\hline & \multicolumn{2}{|c|}{ Poor prognosis (All) } & \multirow[t]{2}{*}{$\mathbf{p}^{*}$} \\
\hline & Absent (\%) & Yes (\%) & \\
\hline HAPS-0 & $47(62)$ & $28(4 I)$ & 0.013 \\
\hline HAPS + & $29(38)$ & 40 (59) & \\
\hline & \multicolumn{2}{|c|}{$\begin{array}{l}\text { Poor prognosis (in-hospital } \\
\text { mortality and ICU care) }\end{array}$} & \\
\hline & Absent (\%) & Yes (\%) & \\
\hline HAPS-0 & $72(56)$ & $3(19)$ & 0.004 \\
\hline HAPS + & $56(44)$ & $13(81)$ & \\
\hline
\end{tabular}

"Chi-square test. HAPS: Harmless acute pancreatitis score; ICU: Intensive care unit. and in-hospital mortality ( $p=0.004)$ (Table 4). The specificity and positive predictive value (PPV) of HAPS were $81 \%$ and $96 \%$, respectively, and the odds ratio was 5.57 (I.5I-20.50, $p=0.009)$. High Ranson's scores were statistically significant for only long hospitalization times $(p=0.00)$. Predicting inhospital mortality and the need for ICU care were not significant ( $p=0.43$ and 0.50 , respectively). Detailed data of the eight patients who died in hospital are provided in Table 5.

Logistic regression analysis was performed for defining parameters that can be used for predicting poor prognosis in HAPS+ patients. Age $(p=0.023)$ and the presence of pancreatic necrosis $(p=0.018)$ were significant independent variables. In particular, pancreatic necrosis had a significantly high odds ratio, and the difference between upper and lower limits at $95 \%$ confidence interval was very high. The presence of peritonitis signs on physical examination had a high odds ratio, although not significant (Table 6). If age $<65$ years was included as a new variable to the HAPS, then $p$ value became significant $(p=0.004)$.

\section{DISCUSSION}

AP usually presents with acute persistent upper abdominal pain, nausea, and vomiting. The two most common etiologies for AP are gallstones and alcohol consumption. ${ }^{[7]}$ Gallstones are the most common etiology for AP in our study as it was shown in the previous study findings. Gallstones were common in females in our study. Alcoholic pancreatitis was rare $(1.4 \%)$ in our study population, in contrast to previous knowledge, and these patients were males. The most reasonable factor for this result is the low chronic alcohol consumption ratios for Turkey.

Although AP usually begins as a mild disease and the majority of patients run a mild course, detecting the small portion of patients who will progress to a severe disease is important. It is essential to identify this subgroup of patients who will go on to develop adverse outcomes and severe disease early on in the disease course. If appropriate aggressive treatment modalities are administered in the early stage of the disease, then the mortality rates can be lowered. ${ }^{[8]}$ Over the recent years, various single- and multi-parameter scoring systems have been identified and tested in patients for predicting the severe course of AP. In 1974, Ranson ${ }^{[9]}$ and colleagues first presented a prognostic scoring system. The Atlanta Classification system, the Balthazar score, Modified Glasgow (Imrie), and APACHE II and III scoring systems were then developed. Several authors have compared these various scoring systems in their studies. ${ }^{[10,11]}$ The major problem for these scoring systems is the length of time needed for calculation and their not easily obtainable several complex component requirements. Another problem is administering aggressive treatment modalities to all patients until calculating the entire score trying to find the severe AP. A majority of AP patients who will run a mild course unnecessarily undergo aggressive 
Table 5. Etiology of pancreatitis, risk scores, detailed imaging data, and clinical course of the in-hospital mortality patients

\begin{tabular}{|c|c|c|c|c|c|c|}
\hline $\begin{array}{l}\text { Agel } \\
\text { Sex }\end{array}$ & $\begin{array}{l}\text { Etiology of } \\
\text { pancreatitis }\end{array}$ & HAPS & Ranson & CT findings & ICU & Death \\
\hline $40 / F$ & Hyperlipidemia & HAPS-0 & 2 (low risk) & $\begin{array}{l}\text { Blurring of peripancreatic } \\
\text { fat and fluid }\end{array}$ & No & $\begin{array}{l}\text { Syncope after standing from the bed in the ward, } \\
\text { followed by dyspnea. Cardiac arrest due to } \\
\text { possible massive pulmonary embolism and exitus. }\end{array}$ \\
\hline $62 / M$ & $\begin{array}{l}\text { Drug (steroid) } \\
\text { Devic syndrome }\end{array}$ & HAPS + & I (low risk) & $\begin{array}{l}\text { Blurring of peripancreatic fat, } \\
\text { pancreatic necrosis }\end{array}$ & Yes & $\begin{array}{c}\text { Dyspnea, followed by respiratory arrest. } \\
\text { Cardiac arrest in ICU and exitus. }\end{array}$ \\
\hline $62 / M$ & Gallstone & HAPS + & 3 (high risk) & $\begin{array}{l}\text { Pancreatic necrosis, } \\
\text { free fluid in abdomen }\end{array}$ & Yes & $\begin{array}{l}\text { Acute renal failure and dialysis, } \\
\text { surgical operation (necrosectomy, colectomy, } \\
\text { T-tube drainage), recurrent abdominal lavages, } \\
\text { exitus in the ICU with multi-organ failure }\end{array}$ \\
\hline $80 / F$ & Unknown & HAPS + & 2 (low risk) & $\begin{array}{l}\text { Pancreatic necrosis, } \\
\text { free fluid in the abdomen, } \\
\text { pleural fluid (bilateral) }\end{array}$ & No & $\begin{array}{l}\text { Irregulated blood glucose levels, } \\
\text { sudden cardiac arrest and exitus }\end{array}$ \\
\hline $58 / F$ & $\begin{array}{l}\text { Periampullary } \\
\text { tm }\end{array}$ & HAPS-0 & I (low risk) & $\begin{array}{l}\text { Gas densities in pancreas, } \\
\text { ampullary tm, } \\
\text { cholecystitis }\end{array}$ & No & $\begin{array}{l}\text { All vital signs are normal, sudden hypotension } \\
\text { at the first day of hospitalization in general ward. } \\
\text { Cardiac arrest due to possible massive pulmonary } \\
\text { embolism or acute myocardial infarction and exitus. }\end{array}$ \\
\hline $64 / F$ & Unknown & HAPS + & 2 (low risk) & $\begin{array}{l}\text { Coledoccal dilatation, } \\
\text { gallbladder normal, } \\
\text { free fluid in the abdomen }\end{array}$ & Yes & $\begin{array}{l}\text { Surgical operation, perforation of gallbladder duct, } \\
\text { exitus in the ICU with multi-organ failure. }\end{array}$ \\
\hline $56 / M$ & Unknown & HAPS + & 3 (high risk) & $\begin{array}{l}\text { Blurring of peripancreatic fat, } \\
\text { pancreatic necrosis, } \\
\text { free fluid in the abdomen }\end{array}$ & Yes & $\begin{array}{l}\text { Acute renal failure and dialysis, } \\
\text { surgical operation (necrosectomy and } \\
\text { recurrent abdominal lavages), } \\
\text { exitus in the ICU with multi-organ failure }\end{array}$ \\
\hline $75 / M$ & Gallstone & HAPS + & 2 (low risk) & $\begin{array}{l}\text { Blurring of peripancreatic fat, } \\
\text { calcifications, atherosclerosis }\end{array}$ & Yes & $\begin{array}{l}\text { COPD acute exacerbation, fever, dyspnea, } \\
\text { exitus in the ICU with multi-organ failure. }\end{array}$ \\
\hline
\end{tabular}

M: Male; F: Female; ICU: Intensive care unit; CT: Computed tomography; HAPS: Harmless Pancreatitis Score; COPD: Chronic obstructive pulmonary disease.

Table 6. Logistic regression analysis for defining parameters that can be used for predicting poor prognosis in HAPS+ patients

\begin{tabular}{lcccc}
\hline Variable & $\begin{array}{l}\text { Odds } \\
\text { ratio }\end{array}$ & \multicolumn{2}{c}{$\mathbf{9 5 \%}$ Cl for odds } & p* \\
\cline { 3 - 4 } & & Lower & Upper & \\
\hline Sex & 1.741 & 0.752 & 4.034 & 0.196 \\
Age & 1.032 & 1.004 & 1.060 & 0.023 \\
Guarding & 1.497 & 0.605 & 3.701 & 0.383 \\
Rebound tenderness & 7.621 & 0.844 & 68.775 & 0.070 \\
Creatinine & 1.427 & 0.800 & 2.544 & 0.228 \\
Hematocrit & 0.955 & 0.884 & 1.032 & 0.244 \\
Pancreatic necrosis & 14.064 & 1.586 & 124.705 & 0.018 \\
\hline
\end{tabular}

"Chi-square test and Mann-Whitney U test; HAPS: Harmless acute pancreatitis score; $\mathrm{Cl}$ : Confidence interval.

modalities. The stated problems make these scores useless to the emergency physicians. Newer scoring systems, such as BISAP, Panc 3 score and Japanese severity score, seem to address the need for risk stratification during the ED stay and are potentially more useful to emergency physicians; however, they remain inadequate. ${ }^{[4]}$ Differently from the other scoring systems, the aim of HAPS is to differentiate harmless AP patients who do not need intensive care from those with a severe AP course. In the initial study of Lankisch and colleagues including 394 patients, HAPS could identify patients who would have a mild disease with a specificity of $97 \%$ and a PPV of $98 \%$ within approximately 30 min of admission. The multicenter validation set including 452 patients confirmed the initial set results. ${ }^{[5]} \mathrm{A}$ few additional retrospective and prospective studies have reported similar results and confirmed and concluded on the usability of HAPS. ${ }^{[6,12-15]}$ Our present study confirmed the significant predictability of HAPS with a high specificity and PPVs ( $81 \%$ and $96 \%$, respectively). In the HAPS-0 group, two patients died in hospital. Detailed investigation of all records of these two patients revealed that both died on the first day of their hospital admission. The first patient had recurrent AP attacks due to hyperlipidemia, and the second patient had a tumor and got an additional 
AP attack. Both patients carry high risk for sudden death, independent from the AP attack, and deaths occurring on the first hospitalization day seem to be caused by their underlying conditions rather than the present AP attack and complications. These findings are also supporting evidence for the usefulness of HAPS for predicting mild AP.

In a recent pilot study, authors evaluated the feasibility of home monitoring instead of hospitalization for patients who were classified as having mild AP using HAPS and Imrie scores. They have shown that home monitoring of patients with mild non-alcoholic AP is as safe and effective as hospitalization and is associated with significantly less costs. ${ }^{[16]}$ Although this was a pilot study and needs validation with further studies, it has a promising result for using HAPS to find the cost-effective home treatment option that is feasible for patients and can protect them from aggressive management modalities and additional problems that may occur during hospitalization. Observing mild AP patients in a ward bed instead of in the ICU or early oral feeding can be other options. New reviews on AP treatment recommend similar modalities. ${ }^{[7]}$ Because of the retrospective design of our present study, these options could not be evaluated.

We have calculated first admission Ranson's scores of patients. The predictability of Ranson's score was not statistically significant. Only two patients among the eight who had in-hospital mortality had a high risk Ranson's score. Further, the measure of agreement $(\kappa)$ between HAPS- 0 and Ranson's low-risk group estimated a slightly low agreement. These findings suggest that HAPS can be more useful for ED than is Ranson's score. Because, for predicting disease severity, the first hours after the patient is admitted to ED is more important, the 48-h Ranson's scores were not calculated. It is also well known that only admission calculations of Ranson's scores, without combining with the score at 48-h, is inadequate.

Logistic regression analysis of our present study revealed age and pancreatic necrosis as significant independent variables. The prognostic value of pancreatic necrosis was shown in the previous studies. ${ }^{[17-19]}$ However, peri-pancreatic fluid and necrosis cannot be seen in the early stage of the disease. Also, imaging all patients in the early phase result in unnecessary radiation exposure to mild AP patients and is not a cost-effective approach for healthcare systems. Therefore, imaging with CT is recommended at $48-72 \mathrm{~h}$ after the diagnosis. ${ }^{[20]}$ Detecting localized pancreatic complications on abdominal CT scan cannot predict systemic mortality and AP outcomes. In a recent study determining the role of HAPS and BISAP score and CRP value together for predicting the presence of pancreatic necrosis on $C T$ at $72 \mathrm{~h}$ revealed that all scores significantly correlated with the occurrence of $C T$ findings. They suggested that CT abdomen can be avoided in patients in whom the scores are not predictive of severe disease, thereby limiting radiation exposure and expenses in
AP. ${ }^{[13]}$ HAPS was statistically significant for predicting pancreatic necrosis in our present study.

Logistic regression analysis of our present study revealed age as another significant independent variable. Patients with a poor prognosis were significantly older than the whole population. Including age $<65$ years as a new and easy variable to HAPS made $p$ values more significant. Thus, we suggest using HAPS plus age $<65$ years scoring system as modified HAPS. The usefulness of modified HAPS should be studied in further prospective studies.

In conclusion, HAPS is a simple and useful scoring algorithm to predict the non-severe course of AP in ED. HAPS-0 patients did not require early aggressive treatments and advanced radiological screening tools in the early stages of the disease.

\section{Conflict of interest: None declared.}

\section{REFERENCES}

1. Flasar MH, Goldberg E. Acute abdominal pain. Med Clin North Am. 2006;90:481-503. [CrossRef]

2. Frossard JL, Steer ML, Pastor CM. Acute pancreatitis. Lancet 2008;371:143-52. [CrossRef]

3. Banks PA, Freeman ML. Practice Parameters Committee of the American College of Gastroenterology. Practice guidelines in acute pancreatitis. Am J Gastroenterol 2006;101:2379-400. [CrossRef]

4. Kuo DC, Rider AC, Estrada P, Kim D, Pillow MT. Acute Pancreatitis: What's the Score? J Emerg Med 2015;48:762-70. [CrossRef]

5. Lankisch PG, Weber-Dany B, Hebel K, Maisonneuve P, Lowenfels $\mathrm{AB}$. The harmless acute pancreatitis score: a clinical algorithm for rapid initial stratification of nonsevere disease. Clin Gastroenterol Hepatol 2009;7:702-5. [CrossRef]

6. Oskarsson V, Mehrabi M, Orsini N, Hammarqvist F, Segersvärd R, Andrén-Sandberg A, et al. Validation of the harmless acute pancreatitis score in predicting nonsevere course of acute pancreatitis. Pancreatology 2011;11:464-8. [CrossRef]

7. Lankisch PG, Apte M, Banks PA. Acute pancreatitis. Lancet 2015;386:85-96. [CrossRef]

8. Brivet FG, Emilie D, Galanaud P. Pro- and anti-inflammatory cytokines during acute severe pancreatitis: an early and sustained response, although unpredictable of death. Parisian study group on acute pancreatitis. Crit Care Med 1999;27:749-55. [CrossRef]

9. Ranson JH, Rifkind KM, Roses DF, Fink SD, Eng K, Localio SA. Objective early identification of severe acute pancreatitis. Am J Gastroenterol 1974;61:443-51.

10. Lee KJ, Kim HM, Choi JS, Kim YJ, Kim YS, Cho JH. Comparison of Predictive Systems in Severe Acute Pancreatitis According to the Revised Atlanta Classification. Pancreas 2016;45:46-50. [CrossRef]

11. Khanna AK, Meher S, Prakash S, Tiwary SK, Singh U, Srivastava A, et al. Comparison of Ranson, Glasgow, MOSS, SIRS, BISAP, APACHEII, CTSI scores, IL-6, CRP, and procalcitonin in predicting severity, organ failure, pancreatic necrosis, and mortality in acute pancreatitis. HPB Surg 2013;2013:367581. [CrossRef]

12. Talukdar R, Sharma M, Deka A, Teslima S, Dev Goswami A, Goswami A, et al. Utility of the "harmless acute pancreatitis score" in predicting a 
non-severe course of acute pancreatitis: a pilot study in an Indian cohort. Indian J Gastroenterol 2014;33:316-21. [CrossRef]

13. Vinish DB, Abishek V, Sujatha K, Arulprakash S, Solomon R, Ganesh $\mathrm{P}$. Role of bedside pancreatic scores and $\mathrm{C}$-reactive protein in predicting pancreatic fluid collections and necrosis. Indian J Gastroenterol. 2017;36:43-9. [CrossRef]

14. Al-Qahtani HH, Alam MKh, Waheed M. Comparison of Harmless Acute Pancreatitis Score with Ranson's Score in Predicting the Severity of Acute Pancreatitis. J Coll Physicians Surg Pak 2017;27:75-9.

15. Gülen B, Sonmez E, Yaylaci S, Serinken M, Eken C, Dur A, et al. Effect of harmless acute pancreatitis score, red cell distribution width and neutrophil/lymphocyte ratio on the mortality of patients with nontraumatic acute pancreatitis at the emergency department. World J Emerg Med 2015;6:29-33. [CrossRef]

16. Ince AT, Senturk H, Singh VK, Yildiz K, Danalioğlu A, Cinar A, et al.
A randomized controlled trial of home monitoring versus hospitalization for mild non-alcoholic acute interstitial pancreatitis: a pilot study. Pancreatology 2014;14:174-8. [CrossRef]

17. Balthazar EJ, Robinson DL, Megibow AJ, Ranson JH. Acute pancreatitis: value of CT in establishing prognosis. Radiology 1990;174:331-6.

18. Bollen TL, Singh VK, Maurer R, Repas K, van Es HW, Banks PA, et al. Comparative evaluation of the modified CT severity index and CT severity index in assessing severity of acute pancreatitis. AJR Am J Roentgenol 2011;197:386-92. [CrossRef]

19. Simchuk EJ, Traverso LW, Nukui Y, Kozarek RA. Computed tomography severity index is a predictor of outcomes for severe pancreatitis. Am J Surg 2000;179:352-5. [CrossRef]

20. Tenner S, Baillie J, DeWitt J, Vege SS; American College of Gastroenterology. American College of Gastroenterology guideline: management of acute pancreatitis. Am J Gastroenterol. 2013;108:1400-15. [CrossRef]

\section{ORİIINAL ÇALIŞMA - ÖZET}

\section{Akut pankreatit prognozunu tahmin etmede HAPS'nin değeri \\ Dr. Ali Vefa Sayraç, ${ }^{1}$ Dr. Yıldıray Cete, ${ }^{2}$ Dr. Özlem Yiğit, ${ }^{2}$ Dr. Alp Giray Aydın, ${ }^{3}$ Dr. Neslihan Sayrac ${ }^{1}$}

1Sağlık Bilimleri Üniversitesi Antalya Eğitim ve Araştırma Hastanesi, Acil Tıp Kliniği, Antalya
${ }^{2}$ Akdeniz Üniversitesi Tıp Fakültesi, Acil Tıp Anabilim Dalı, Antalya

${ }^{2}$ Akdeniz Üniversitesi Tıp Fakültesi, Acil Tıp Anabilim Dalı, Antalya
${ }^{3}$ Koç Üniversitesi Tıp Fakültesi Hastanesi, Acil Tıp Anabilim Dalı, İstanbul

AMAÇ: Akut pankreatit (AP), erken tanı ve tedavi gerektiren bir karın ağrısı nedenidir. Hastalarda prognozu öngörmede kullanılan birçok skorlama sistemi acil servis gibi az sayıda veri ve hızlı karar verme gerekliliği olan alanlarda kullanışıı değildir. Son dönemde HAPS (Harmless Acute Pancreatitis Score) prognoz tahmin sisteminin güvenilir olduğunu söyleyen çalışmalar yapılmıştır. Bu çalışmanın amacı, acil serviste AP tanısı koyulan hastalarda erken dönemde prognozu tahmin etmede HAPS'nin değerliliğini saptamaktır.

GEREÇ VE YÖNTEM: Bu çalışmada, acil serviste akut pankreatit tanısı alan 16 yaş üstü hastalar geriye dönük olarak incelendi. Çalışmaya 69'u (\%47.9) erkek, 75’i (\%52.I) kadın, yaş ortalaması 58.7 I 5.4 olan I 44 hasta alındı. Hastaların arşiv dosyalarından bilgilerine ulaşıldı. HAPS'nin hafif seyirli pankreatit olgularını saptamadaki başarıı test edildi. Hastaların Ranson skorları da hesaplanarak HAPS ile uyumluluğu karşılaştıııldı.

BULGULAR: HAPS ile pankreatit prognozunu tahmin etme arasındaki ilişki anlamlı bulundu $(p=0.008)$. HAPS spesifitesi \% 8 I, pozitif prediktif değeri \%96, odds oranı 5.57 ( I.5I-20.50, p=0.009) olarak hesaplandı. Ranson skorlarına göre bakıldığında ise istatistiksel anlamlı fark saptanmadı. HAPS ile Ranson skorlarının uyumluluğu için hesaplanan kappa değeri 0.15 - zayıf uyumluluk olarak bulundu.

TARTIŞMA: HAPS acil servise başvuran ve klinik olarak hafif seyredecek pankreatit hastalarını tespit etmede, basit ve kolay uygulanabilir değerli bir skorlama sistemi olabilir. HAPS-0 olan hastalarda, agresif tedavi girişimlerine ve erken dönemde ileri görüntüleme incelemelerine ihtiyaç yoktur. Anahtar sözcükler: Acil servis; akut pankreatit; prognoz; zararsız akut pankreatit skoru.

Ulus Travma Acil Cerrahi Derg 2018;24(4):327-332 doi: 10.5505/tjtes.2017.50794 